\title{
SPATIAL VARIABILITY OF IRRIGATED COMMON BEAN YIELD CORRELATED WITH THE FERTILITY OF A SANDY SOIL
}

\author{
Job T. de Oliveira ${ }^{*}$, Cassiano G. Roque ${ }^{2}$, \\ Paulo Teodoro ${ }^{2}$, Rafael Montanari ${ }^{3}$
}

${ }^{1 *}$ Corresponding author. Universidade Federal do Maranhão (UFMA), Centro de Ciências Agrárias e Ambientais/ Chapadinha - MA, Brasil. E-mail: job.oliveira@ hotmail.com | ORCID ID: http://orcid.org/0000-0001-9046-0382

\section{KEYWORDS}

precision agriculture, geostatistics, soil management, irrigation, (Phaseolus vulgaris $\mathrm{L}$.$) .$

\begin{abstract}
The common bean is widely cultivated in Brazil. In the 2016-2017 growing season, an experiment was carried out in a Typic Quartzipsamment (or Neossolo Quartzarênico) soil in the municipality of Cassilândia, MS, Brazil, with the aim of characterizing specific aspects of soil management, using a linear and spatial correlation between the irrigated yield of common beans and the chemical properties of the soil. Soil samples were collected from layers at depths $0.00-0.10$ and $0.10-0.20 \mathrm{~m}$, within a grid of 117 georeferenced points. A data analysis was carried out using statistical and geostatistical techniques. A multiple regression analysis showed that about $31 \%$ of the grain yield variability of the irrigated common bean crop could be attributed to the spatial variability in the chemical properties of the soil. These properties have a spatial dependence that is classified as moderate and strong, with a predominantly Gaussian-type semivariogram model. Soil properties such as $\mathrm{pH}_{(1)}, \mathrm{pH}_{(2)}, \mathrm{S}_{(2)}$ and $\mathrm{V} \%_{(2)}$ can be considered potential indicators of the grain yield of an irrigated common bean crop when cultivated in a sandy soil under a no-tillage system.
\end{abstract}

\section{INTRODUCTION}

The common bean (Phaseolus vulgaris L.) is widely cultivated in Brazil, and is an essential and nutritious component of the diet of the Latin-American population, mainly due to its high content of proteins and minerals. In the 2019-2020 harvest, the total area of common bean cultivation was 2.909 million hectares, with a production of 3.022 million tons, which resulted in an average grain yield (GY) of $1,039 \mathrm{~kg} \mathrm{ha}^{-1}$ (Conab, 2020). With the advent of precision agriculture in Brazil, the geostatistical study of the components of crop production in relation to yield has intensified (Oliveira et al., 2018, Tavanti et al., 2020a, b).

Fertilizers and correctives can be applied at varying rates in conjunction with geostatistics. This is one of the tools of precision agriculture that allows for the study of the spatial variability of soil properties, and can indicate alternative approaches to soil management in order to minimize the effect on crop yield of the variability in the soil properties. Thus, after analyzing the spatial variability of soil properties of agricultural interest, it is possible to create maps of spatial variability without trend and with minimum variance using kriging interpolation (Lima et al., 2017a).

The hypothesis of this work is that it is possible to produce common beans in a sustainable way in sandy soils, when combined with the study of specific soil management zones. In this context, the objective of this study was to characterize specific areas of soil management, using the linear and spatial correlation between the irrigated yield of common beans and the chemical properties of a Brazilian Cerrado sandy soil, in order to identify the properties that are most closely related to the increase in yield.

\section{MATERIAL AND METHODS}

Our study was carried out in an area with a centerpivot irrigation system, located at Flor Jardim Farm in Cassilândia, Mato Grosso do Sul State, Brazil, at geographic coordinates $356381.383 \mathrm{~m} \mathrm{~W} ; 7893667.280 \mathrm{~m}$ S (UTM) (Figure 1). The regional climate, according to the Köppen classification, is Aw, i.e. characterized as tropical, with hot summers and a tendency toward high rainfall

\footnotetext{
${ }^{2}$ Universidade Federal do Mato Grosso do Sul (UFMS), Campus Chapadão do Sul/ Chapadão do Sul - MS, Brasil.

${ }^{3}$ Universidade Estadual Paulista "Júlio de Mesquita Filho" (UNESP)/ Ilha Solteira - SP, Brasil.
} 
levels, and dry winters, with a dry season between May and September. The mean annual temperature is $24.2^{\circ} \mathrm{C}$, with a minimum of $16.4^{\circ} \mathrm{C}$ (July) and a maximum of $28.6^{\circ} \mathrm{C}$ (January), and a mean annual rainfall of $1,500 \mathrm{~mm}$.

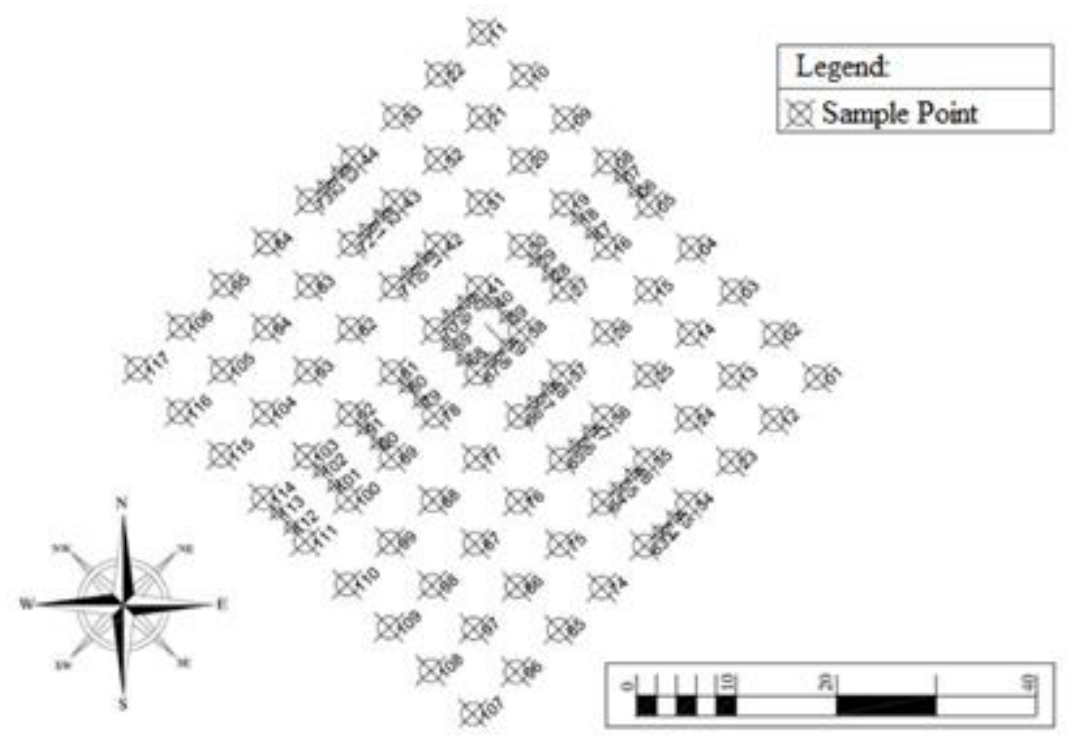

FIGURE 1. Detail of the sampling grid used at Flor Jardim Farm in Cassilândia, Mato Grosso do Sul State, Brazil, for cultivating common beans.

The experimental grids were installed in a deep sandy soil, classified as Neossolo Quartzarênico Órtico latossólico - RQo (Embrapa, 2018) or Typic Quartzipsamment. The results of the physical and chemical analyses are shown in Table 1.

TABLE 1. Physical and chemical properties ${ }^{(1)}$ of Brazilian Cerrado sandy soil used for the cultivation of common beans.

\begin{tabular}{|c|c|c|c|c|c|c|c|c|c|c|c|c|c|c|c|}
\hline \multirow{2}{*}{ Depth } & \multicolumn{3}{|c|}{ Particle size } & \multicolumn{12}{|c|}{ Chemical properties } \\
\hline & Sand & Silt & Clay & $\mathrm{pH}$ & $\mathrm{P}$ & $\mathrm{OM}$ & $\mathrm{K}^{+}$ & $\mathrm{Ca}^{2+}$ & $\mathrm{Mg}^{2+}$ & $\mathrm{H}+\mathrm{Al}$ & $\mathrm{Al}^{3+}$ & $\mathrm{S}$ & CEC & $\mathrm{V} \%$ & $\mathrm{~m} \%$ \\
\hline $\mathrm{m}$ & ---- & $\mathrm{kg}^{-1}$ & ----- & & $\mathrm{mg} \mathrm{dm}{ }^{-3}$ & $\mathrm{~g} \mathrm{dm}^{-3}$ & & ------ & $---m$ & $\mathrm{~mol}_{\mathrm{c}} \mathrm{dr}$ & ${ }^{-3}--$ & - & & $---\%$ & --- \\
\hline $0.0-0.20$ & 946 & 11 & 43 & 5.4 & 8 & 13 & 0.2 & 17 & 8 & 13 & 0 & 25.2 & 38.2 & 66 & 0 \\
\hline $0.20-0.40$ & 932 & 20 & 48 & 5.1 & 12 & 10 & 0.5 & 7 & 2 & 15 & 1 & 9.5 & 24.5 & 39 & 10 \\
\hline
\end{tabular}

Particle size analysis was performed by the pipette method; $\mathrm{pH}$ in $0.01 \mathrm{~mol} \mathrm{~L}^{-1} \mathrm{CaCl}_{2}$; soil:solution ratio (1:2.5). OM: Organic matter, Walkley-Black method. P, K, Ca, Mg and Al were extracted by the resin method. S: Sum of bases $(\mathrm{S}=\mathrm{Ca}+\mathrm{Mg}+\mathrm{K})$. CEC: cationic exchange capacity. V\%: soil base saturation. $\mathrm{m} \%$ : $\mathrm{Al}^{3+}$ saturation.

The experiment was conducted under a no-tillage system in an area with a center-pivot irrigation system. The weeds in the experimental area were desiccated with glyphosate herbicide WG $\left(2.0 \mathrm{~kg} \mathrm{ha}^{-1}\right)$ at a spray volume of $200 \mathrm{~L} \mathrm{ha}^{-1}$. The common bean $c v$. Elite was sown mechanically on July 7 th, 2016, in rows $0.45 \mathrm{~m}$ apart, with a density of 11 seeds $\mathrm{m}^{-1}$ (or 246,914 seeds per hectare). The management of weeds, pests, and diseases was carried out according to the needs and technical recommendations for the crop. Harvesting was performed manually on October 15th, 2016, 95 days after the emergence of plants.

The $x$ and $y$ directions of the Cartesian coordinate system were defined, and at the end of the phenological cycle of the common bean (October 5th, 2016), the experimental grid was staked out. Each grid consisted of nine transects of $48 \times 48 \mathrm{~m}$. These transects were spaced 6.0 $\mathrm{m}$ apart, with sample points squared in $6.0 \times 6.0 \mathrm{~m}$, containing 81 of them. However, they were also allocated within a larger grid, with a spacing of $2.0 \mathrm{~m}$ between points (i.e. a grid with a higher density). This higher-density grid contained 36 points, giving a total of 117 sample points throughout the study area (Figure 1). This type of sampling, using grids with higher density within a larger grid, has also been used in previous studies (Montanari et al., 2013a, b).

The GY was individually determined at each sampling point, which was composed of four rows of plants of length $1.8 \mathrm{~m}$, giving a total area of $3.24 \mathrm{~m}^{2}$. Grains were cleaned and weighed, and the GY (in kg ha ${ }^{-1}$ ) was estimated after the correction of grain weights to $13 \%$ of moisture.

At each sampling point, soil samples were collected from the $0.0-0.10$ and $0.10-0.20 \mathrm{~m}$ layers using a hole-type auger. After collection, samples were air-dried, passed through a sieve with mesh size $2.0 \mathrm{~mm}$, and submitted to chemical analysis in the Soil Fertility Laboratory of the Federal University of Mato Grosso do Sul, in Chapadão do Sul, MS, Brazil. The $\mathrm{pH}$ of the soil was determined potentiometrically in a $0.01 \mathrm{~mol} \mathrm{~L}^{-1} \mathrm{CaCl}_{2}$ solution, with a soil:solution ratio of $1: 2.5$, using a combined calomel reference glass electrode and $\mathrm{pH}$ meter. Phosphorus $(\mathrm{P})$ was extracted using an ion-exchange resin and determined using 
the colorimetric method at a wavelength of $725 \mathrm{~nm}$. Basic cations $\left(\mathrm{Ca}^{2+}, \mathrm{Mg}^{2+}\right.$, and $\left.\mathrm{K}^{+}\right)$were extracted by ionexchange resin and determined by atomic absorption spectrophotometry. Exchangeable aluminum $\left(\mathrm{Al}^{3+}\right)$ was extracted using an ion-exchange resin and determined by titration with $0.025 \mathrm{~mol} \mathrm{~L}^{-1} \mathrm{NaOH}$. The cation exchange capacity (CEC) was estimated by the summation method $(\mathrm{CEC}=\mathrm{H}+\mathrm{Al}+\mathrm{Ca}+\mathrm{Mg}+\mathrm{K})$. From this data, we also calculated the soil base saturation (V\%), soil aluminum saturation $(\mathrm{m} \%)$, and the amount of limestone needed (LN) to increase the soil base saturation to $70 \%$. All the chemical properties of the soil were determined by adopting the standard procedures recommended by Teixeira et al. (2017).

For all the chemical properties of the soil and the GY of common beans, a descriptive analysis was carried out using RBio statistical software (Bhering, 2017). The average, median, minimum and maximum values, standard deviation, coefficient of variation, kurtosis, and asymmetry were calculated. A frequency distribution analysis was also performed. Thus, a test at $5 \%$ of significance was used to test the hypothesis of normality or lognormality of the chemical properties of the soil $(x)$. This statistical test allowed us to test the null hypothesis, which was assumed to be a sample from a population with a normal distribution.

In order to characterize the structure and magnitude of the spatial dependence of the chemical properties of the soil and the GY, semivariogram adjustments and a semivariance estimation were performed to estimate the coefficients of the theoretical model; these coefficients are called the nugget effect $\left(\mathrm{C}_{0}\right)$, the sill $\left(\mathrm{C}_{0}+\mathrm{C}\right)$, and the range $\left(\mathrm{A}_{0}\right)$. After the semivariograms were adjusted, the data were interpolated by kriging in order to allow visualization of the spatial distribution patterns of the soil properties using maps. Standard error maps of kriging prediction were generated. These maps refer to the standard deviation of the prediction for any individual point, and are obtained to gather information on the confidence in the interpolated values in the study area. Cross-validation is a tool that is used to evaluate alternative models of simple and crossed semivariograms, which will perform kriging and cokriging, respectively. In this analysis, each point contained within the spatial domain was removed individually, and its value was estimated as if it did not exist. In this way, a graph of estimated versus observed values could be constructed for all points.

\section{RESULTS AND DISCUSSION}

The results of this descriptive analysis of the chemical properties of the soil are shown in Table 2. The $\mathrm{pH}$ was the only characteristic that had a low value of the coefficient of variation for the two depths sampled, with values of $\mathrm{pH}_{(1)} 8.7 \%$ and $\mathrm{pH}_{(2)} 6.8 \%$. Dalchiavon et al. (2011) evaluated the spatial variability of the common bean as a function of the chemical properties of a Latossolo Vermelho distroférrico soil with a no-tillage system, and also observed a low coefficient of variation (7.3\%) for the soil $\mathrm{pH}$ at a depth of $0.0-0.20 \mathrm{~m}$. 
TABLE 2. Initial descriptive statistics of the yield of common beans and the main chemical and physical properties of a Brazilian Cerrado sandy soil, Cassilândia, MS, Brazil.

Properties $^{(a)}$ Average Minimum Maximum $\begin{gathered}\text { Standard Coefficient } \\ \text { deviation of variation }\end{gathered}$ Kurtosis Asymmetry $\operatorname{Pr}>\mathrm{F}^{\text {(b) }}$

\begin{tabular}{|c|c|c|c|c|c|c|c|c|c|}
\hline$\overline{\mathrm{GY}}$ & $1,089.0$ & 328.0 & $1,992.0$ & 340.50 & 31.3 & -0.193 & 0.197 & 0.6540 & $\mathrm{NO}$ \\
\hline $\mathrm{pH}_{(1)}$ & 4.9 & 3.8 & 6.1 & 0.42 & 8.7 & -0.012 & 0.263 & 0.2110 & NO \\
\hline $\mathrm{pH}_{(2)}$ & 5.3 & 4.3 & 6.0 & 0.36 & 6.8 & 0.135 & -0.533 & 0.0070 & ID \\
\hline$P_{(1)}$ & 6.2 & 0.9 & 23.4 & 4.28 & 68.7 & 5.606 & 2.23 & 0.0001 & ID \\
\hline$P_{(2)}$ & 16.3 & 2.0 & 39.9 & 11.21 & 68.6 & -0.625 & 0.825 & 0.0001 & ID \\
\hline $\mathrm{K}^{+}{ }_{(1)}$ & 1.0 & 0.1 & 2.4 & 0.50 & 48.1 & 0.060 & 0.828 & 0.0001 & ID \\
\hline $\mathrm{K}^{+}(2)$ & 0.9 & 0.2 & 2.8 & 0.54 & 58.1 & 1.103 & 1.245 & 0.0001 & ID \\
\hline $\mathrm{Ca}^{2+}{ }_{(1)}$ & 13.6 & 2.0 & 23.6 & 3.61 & 26.6 & 0.824 & -0.382 & 0.1440 & NO \\
\hline $\mathrm{Ca}^{2+}{ }_{(2)}$ & 9.2 & 0.1 & 15.4 & 3.18 & 34.5 & 1.404 & -1.028 & 0.0001 & ID \\
\hline $\mathrm{Mg}^{2+}{ }_{(1)}$ & 2.7 & 0.0 & 7.6 & 1.60 & 59.2 & -0.119 & 0.432 & 0.0440 & $\mathrm{TN}$ \\
\hline $\mathrm{Mg}^{2+}(2)$ & 6.5 & 0.1 & 28.1 & 7.14 & 110.6 & 0.346 & 1.128 & 0.0001 & ID \\
\hline $\mathrm{H}+\mathrm{Al}_{(1)}$ & 14.0 & 4.1 & 24.8 & 4.73 & 33.8 & -0.554 & 0.063 & 0.0740 & NO \\
\hline $\mathrm{H}+\mathrm{Al}_{(2)}$ & 14.2 & 4.1 & 25.9 & 5.09 & 35.8 & -0.921 & 0.146 & 0.0160 & ID \\
\hline $\mathrm{Al}^{3+}{ }_{(1)}$ & 0.6 & 0.6 & 1.2 & 0.12 & 19.6 & 18.345 & 4.448 & 0.0001 & ID \\
\hline $\mathrm{Al}^{3+}{ }_{(2)}$ & 0.6 & 0.6 & 3.9 & 0.32 & 49.7 & 91.205 & 9.173 & 0.0001 & ID \\
\hline$S_{(1)}$ & 17.3 & 2.5 & 30.7 & 4.89 & 28.3 & 0.316 & -0.325 & 0.2020 & NO \\
\hline $\mathrm{S}_{(2)}$ & 16.6 & 0.5 & 37.4 & 7.80 & 47.0 & 0.000 & 0.387 & 0.0830 & $\mathrm{NO}$ \\
\hline $\mathrm{CEC}_{(1)}$ & 31.3 & 15.7 & 44.8 & 5.02 & 16.1 & 0.890 & -0.224 & 0.2590 & $\mathrm{NO}$ \\
\hline $\mathrm{CEC}_{(2)}$ & 30.8 & 12.1 & 53.1 & 8.30 & 26.9 & -0.137 & 0.272 & 0.2100 & $\mathrm{NO}$ \\
\hline $\mathrm{V} \%_{(1)}$ & 55.3 & 10.1 & 83.8 & 13.88 & 25.1 & 0.288 & -0.384 & 0.2500 & NO \\
\hline $\mathrm{V} \%_{(2)}$ & 52.3 & 3.8 & 84.1 & 17.19 & 32.9 & 0.670 & -0.666 & 0.0020 & ID \\
\hline $\mathrm{m} \%_{(1)}$ & 3.7 & 1.9 & 8.0 & 1.09 & 29.7 & 1.105 & 1.018 & 0.0001 & ID \\
\hline $\mathrm{m} \%_{(2)}$ & 6.2 & 1.3 & 80.8 & 11.13 & 180.3 & 28.336 & 5.165 & 0.0001 & ID \\
\hline $\mathrm{LN}_{(1)}$ & 0.5 & 0.0 & 1.8 & 0.43 & 78.6 & -0.297 & 0.528 & 0.0001 & ID \\
\hline $\mathrm{LN}_{(2)}$ & 0.6 & 0.0 & 1.9 & 0.47 & 79.7 & -0.455 & 0.502 & 0.0001 & ID \\
\hline
\end{tabular}

(a) GY: grain yield $\left(\mathrm{kg} \mathrm{ha}^{-1}\right)$; the subscripts (1) and (2) for each soil property refer to the depth of the layer from which samples were collected, i.e. $0.00-0.10$ and $0.10-0.20 \mathrm{~m}$, respectively. $\mathrm{pH}_{(1)}$ and $\mathrm{pH}_{(2)}$ : $\mathrm{pH}$ value in $\mathrm{CaCl}_{2} ; \mathrm{P}_{(1)}$ and $\mathrm{P}_{(2)}$ : phosphorus content $\left(\mathrm{mg} \mathrm{dm}^{-3}\right)$; $\mathrm{K}^{+}(1)$ and $\mathrm{K}^{+}(2)$ : potassium content $\left(\mathrm{mmol}_{\mathrm{c}} \mathrm{dm}^{-3}\right) ; \mathrm{Ca}^{2+}{ }_{(1)}$ and $\mathrm{Ca}^{2+}{ }_{(2)}$ : calcium content $\left(\mathrm{mmol}_{\mathrm{c}} \mathrm{dm}^{-3}\right) ; \mathrm{Mg}^{2+}{ }_{(1)}$ and $\left.\mathrm{Mg}^{2+}{ }_{(2)}\right)$ : magnesium content (mmolc $\left.\mathrm{dm}^{-3}\right)$; $\mathrm{H}+\mathrm{Al}_{(1)}$ and $\mathrm{H}+\mathrm{Al}_{(2)}$ : potential acidity $\left(\mathrm{mmol}_{\mathrm{c}} \mathrm{dm}^{-3}\right) ; \mathrm{Al}^{3+}{ }_{(1)}$ and $\mathrm{Al}^{3+}{ }_{(2)}$ : aluminum content $\left(\mathrm{mmol}_{\mathrm{c}} \mathrm{dm}^{-3}\right)$; $\mathrm{S}_{(1)}$ and $\mathrm{S}_{(2)}$ : sum of bases $\left(\mathrm{mmol}_{\mathrm{c}}\right.$ $\left.\mathrm{dm}^{-3}\right) ; \mathrm{CEC}_{(1)}$ and $\mathrm{CEC}_{(2)}$ : values of cation exchange capacity $\left(\mathrm{mmol}_{\mathrm{c}} \mathrm{dm}^{-3}\right) ; \mathrm{V} \%_{(1)}$ and $\mathrm{V} \%_{(2)}$ : values of the soil base saturation (\%); $\mathrm{m} \%(1)$ and $\mathrm{m} \%$ (2): values of the aluminum saturation of the soil; and $\mathrm{LN}_{(1)}$ and $\mathrm{LN}_{(2)}$ : amount of limestone needed ( $\mathrm{tha}^{-1}$ ). (b) FD: frequency distribution, where NO: normal type, TN: tending to normal, and ID: indeterminate.

The common bean GY showed a very high coefficient of variation (31.3\%). Dalchiavon et al. (2011) and Silva et al. (2017) analyzed the crop yield of common beans in a dystrophic Red Latosol soil with a no-tillage system, using grids of 135 and 124 sampling points, and also found high values of variability $(20.3 \%$ and $22.2 \%$, respectively) for the GY. However, contradictory results were reported by Montanari et al. (2013b), who evaluated the common bean GY for the same soil and climatic conditions and obtained a mean value for the spatial variability of $18.3 \%$.

The phosphorus content in the $0.0-0.10\left(\mathrm{P}_{(1)}\right)$ and $0.10-0.20 \mathrm{~m}\left(\mathrm{P}_{(2)}\right)$ layers had very high values for the coefficient of variation of $68.7 \%$ and $68.6 \%$, respectively. Dalchiavon et al. (2011) also obtained very high values for the coefficient of variation $(64.5 \%)$ for the P content at a depth of $0.0-0.20 \mathrm{~m}$. The potassium content in the $0.0-0.10$ $\left(\mathrm{K}^{+}{ }_{(1)}\right)$ and $0.10-0.20 \mathrm{~m}\left(\mathrm{~K}^{+}{ }_{(2)}\right)$ layers showed very high coefficients of variation of $48.1 \%$ and $58.1 \%$. Montanari et al. (2016) similarly obtained very high coefficients of variation for the $\mathrm{K}$ content at depths of $0.0-0.10 \mathrm{~m}(\mathrm{CV}=$ $51.2 \%)$ and $0.10-0.20 \mathrm{~m}(\mathrm{CV}=41.9 \%)$.

The calcium content at a depth of $0.0-0.10 \mathrm{~m}$ $\left(\mathrm{Ca}^{2+}{ }_{(1)}\right)$ had a high variability of $26.6 \%$, while in the 0.10 $0.20 \mathrm{~m}$ layer $\left(\mathrm{Ca}^{2+}{ }_{(2)}\right)$, it had a very high variability of $34.5 \%$. The magnesium content in the two sampled depths showed a very high variability of $59.2 \%\left(\mathrm{Mg}^{2+}(1)\right)$ and $110.6 \%\left(\mathrm{Mg}^{2+}(2)\right)$. Similar results were reported by Montanari et al. (2016) and Dalchiavon et al. (2011), who also obtained very high values for the coefficient of variation for the $\mathrm{Ca}^{2+}$ and $\mathrm{Mg}^{2+}$ contents at depths of up to $0.20 \mathrm{~m}$. 
The potential acidity of the soil in the $0.0-0.10 \mathrm{~m}$ $\left(\mathrm{H}+\mathrm{Al}_{(1)}\right)$ and $0.10-0.20 \mathrm{~m}\left(\mathrm{H}+\mathrm{Al}_{(2)}\right)$ layers showed very high values of variability of $33.8 \%$ and $35.8 \%$, respectively. For a Red Latosol, Dalchiavon et al. (2011) observed a high variability $(\mathrm{CV}=20 \%)$ for the potential soil acidity. The exchangeable aluminum content had a medium variability $(\mathrm{CV}=19.6 \%)$ in the $0.0-0.10 \mathrm{~m}$ layer, while the variability in the $0.10-0.20 \mathrm{~m}$ layer was very high $(\mathrm{CV}=49.7 \%)$. The sum of bases had high variability $(\mathrm{CV}=28.3 \%)$ in the 0.0 $0.10 \mathrm{~m}$ layer $\left(\mathrm{S}_{(1)}\right)$ and very high variability $(\mathrm{CV}=47.0 \%)$ in the $0.10-0.20 \mathrm{~m}$ layer $\left(\mathrm{S}_{(2)}\right)$. Dalchiavon et al. (2011) also reported very high values $(\mathrm{CV}=30.4 \%)$ for the variability of the sum of soil bases. The cation exchange capacity in the $0.0-0.10 \mathrm{~m}$ layer $\left(\mathrm{CEC}_{(1)}\right)$ showed medium variability $(\mathrm{CV}=16.1 \%)$, while in the $0.10-0.20 \mathrm{~m}$ layer $\left(\mathrm{CEC}_{(2)}\right)$, the variability was high $(\mathrm{CV}=26.9 \%)$. For a Red Latosol, Dalchiavon et al. (2011) also observed high variability (CV $=20.4 \%$ ) for the cation exchange capacity in the $0.0-0.20$ $\mathrm{m}$ layer. The soil base saturation had high $(\mathrm{CV}=25.1 \%)$ and very high variability $(\mathrm{CV}=32.9 \%)$ for the layers at 0.0 $0.10 \mathrm{~m}\left(\mathrm{~V} \%_{(1)}\right)$ and $0.10-0.20 \mathrm{~m}\left(\mathrm{~V} \%_{(2)}\right)$, respectively. The aluminum saturation $(\mathrm{m} \%)$ had high variability $(\mathrm{CV}=$ $29.7 \%$ ) in the $0.0-0.10 \mathrm{~m}$ layer, while the variability in the $0.10-0.20 \mathrm{~m}$ layer was very high $(\mathrm{CV}=180.3 \%)$. Montanari et al. (2016) similarly observed very high variability for base saturation (V\%) and aluminum saturation $(\mathrm{m} \%)$. The amount of limestone needed for soil correction at the two depths sampled here showed very high variability, with values of $78.6 \%\left(\mathrm{LN}_{(1)}\right)$ and $79.7 \%\left(\mathrm{LN}_{(2)}\right)$.

The medium to very high values of variability observed for most of the chemical properties of the soil and the grain yield may be because the studied soil (Neossolo Quartzarênico Órtico latossólico - RQo) has a sandy texture and low levels of nutrients (see Table 1).

The frequency distributions of the soil properties $\mathrm{pH}_{(2)}, \mathrm{P}_{(1)}, \mathrm{P}_{(2)}, \mathrm{K}_{(1)}, \mathrm{K}_{(2)}, \mathrm{Ca}^{2+}{ }_{(2)}, \mathrm{Mg}^{2+}{ }_{(2)}, \mathrm{H}+\mathrm{Al}_{(2)}, \mathrm{Al}^{3+}{ }_{(1)}$, $\mathrm{Al}^{3+}{ }_{(2)}, \quad \mathrm{V} \%_{(2)}, \mathrm{m} \%_{(1)}, \mathrm{m} \%_{(2)}, \quad \mathrm{LN}_{(1)}$, and $\mathrm{LN}_{(2)}$ were indeterminate (Table 2). Montanari et al. (2016) likewise reported an indeterminate frequency distribution for $\mathrm{pH}_{(2)}$, $\mathrm{P}_{(1)}, \mathrm{P}_{(2)}, \mathrm{K}_{(1)}, \mathrm{K}_{(2)}, \mathrm{Ca}^{2+}(2), \mathrm{Mg}^{2+}{ }_{(2)}, \mathrm{Al}^{3+}{ }_{(1)}, \mathrm{V} \%_{(2)}$, and $\mathrm{m} \%_{(1)}$, supporting the results obtained in this study. Of the soil properties measured here, a normal frequency distribution was observed for $\mathrm{GY}, \mathrm{pH}_{(1)}, \mathrm{Ca}^{2+}{ }_{(1)}, \mathrm{H}+\mathrm{Al}_{(1)}, \mathrm{S}_{(1)}, \mathrm{S}_{(2)}$, $\mathrm{CEC}_{(1)}, \mathrm{CEC}_{(2)}$, and $\mathrm{V} \%(1)$, with respective asymmetries of $0.197,0.263,-0.382,0.063,-0.325,0.387,-0.224,0.272$, and -0.384 , which were shown to be significant by the normality test, since their values varied between 0.0740 and 0.6540 (Table 2).
The average yield of common beans (winter growing season) in this experiment differed from the average yield of the main producing regions for common beans across Brazil during the 2019-2020 season. The average GY in this study $\left(1,089 \mathrm{~kg} \mathrm{ha}^{-1}\right)$ was higher than in the northern and northeastern regions, which had average yields of $933 \mathrm{~kg}$ $\mathrm{ha}^{-1}$ and $431 \mathrm{~kg} \mathrm{ha}^{-1}$, respectively; however, it was lower than the midwestern and southeast regions, which had average yields of $1786 \mathrm{~kg} \mathrm{ha}^{-1}$ and $1592 \mathrm{~kg} \mathrm{ha}^{-1}$, respectively (Conab, 2020). This means that the average GY in the present study was $60 \%$ higher than the average for the northeast region and $39 \%$ lower than the average for the midwestern region, where this study was conducted.

The respective values for $\mathrm{pH}_{(1)}$ and $\mathrm{pH}_{(2)}$ of 4.9 and 5.3 indicate that the $\mathrm{pH}$ increased with soil depth (Table 2). This effect was also observed for the $\mathrm{Mg}^{2+}$ content (from 2.7 to $6.5 \mathrm{mmol}_{\mathrm{c}} \mathrm{dm}^{-3}$ ) and the $\mathrm{P}$ content (from 6.2 to $16.3 \mathrm{mg}$ $\left.\mathrm{dm}^{-3}\right)$. Differing results were reported by Lima et al. (2017b), who observed a decrease in nutrient content in a Cerrado sandy soil fertilized with lime sludge and oxyfertil. The potassium content $\left(\mathrm{K}^{+}{ }_{(1)}=1.0 \mathrm{mmol}_{\mathrm{c}} \mathrm{dm}^{-3}\right.$ and $\mathrm{K}^{+}{ }_{(2)}=$ 0.9 mmol $\left._{\mathrm{c}} \mathrm{dm}^{-3}\right)$ and calcium $\left(\mathrm{Ca}^{2+}{ }_{(1)}=13.6 \mathrm{mmolc}^{-3}\right.$ and $\left.\mathrm{Ca}^{2+}{ }_{(2)}=9.2 \mathrm{mmol}_{\mathrm{c}} \mathrm{dm}^{-3}\right)$ decreased with the soil depth, which was in agreement with the results of Lima et al. (2017b). These results may be due to the soil being sandy and having high macroporosity, which can facilitate the leaching of these nutrients. The values of the potential acidity $\left(\mathrm{H}+\mathrm{Al}_{(1)}=14.0\right.$ mmol $_{\mathrm{c}} \mathrm{dm}^{-3}$ and $\mathrm{H}+\mathrm{Al}_{(2)}=14.2$ $\left.\mathrm{mmol}_{\mathrm{c}} \mathrm{dm}^{-3}\right)$ and aluminum saturation $\left(\mathrm{m} \%_{(1)}\right.$ of $3.7 \%$ and $\mathrm{m} \%_{(2)}$ of $6.2 \%$ ) increased with the depth of the soil. Similar results were also reported by Montanari et al. (2016). The values for the sum of bases $\left(S_{(1)}=17.3 \mathrm{mmol}_{c} \mathrm{dm}^{-3}\right.$ and $S_{(2)}$ $\left.=16.6 \mathrm{mmol}_{\mathrm{c}} \mathrm{dm}^{-3}\right)$, soil base saturation $\left(\mathrm{V} \%_{(1)}=55.3 \%\right.$ and $\left.\mathrm{V} \%_{(2)}=52.3 \%\right)$, and cation exchange capacity $\left(\mathrm{CEC}_{(1)}=\right.$ $31.3 \mathrm{mmol}_{\mathrm{c}} \mathrm{dm}^{-3}$ and $\mathrm{CEC}_{(2)}=30.8 \mathrm{mmol}_{\mathrm{c}} \mathrm{dm}^{-3}$ ) were reduced with depth, a result that also agreed with those of Montanari et al. (2016). The amount of limestone needed $\left(\mathrm{LN}_{(1)}=0.5 \mathrm{t} \mathrm{ha}^{-1}\right.$ and $\left.\mathrm{LN}_{(2)}=0.6 \mathrm{t} \mathrm{ha}^{-1}\right)$ was higher for the deeper layer than the superficial layer. This indicates that the technique used for the application of liming must be carried out with criteria and in an appropriate way so that limestone can be efficiently incorporated into the soil profile.

From a study of Pearson's linear correlation between the yield and the chemical properties of the soil (Figure 2), it was found that there was a positive and highly significant correlation of GY with $\mathrm{pH}_{(1)}(\mathrm{r}=0.412 ; \mathrm{p}=0.01), \mathrm{Mg}^{2+}{ }_{(1)}(\mathrm{r}$ $=0.266 ; \mathrm{p}=0.01), \mathrm{Mg}^{2+}{ }_{(2)}(\mathrm{r}=0.306 ; \mathrm{p}=0.01)$ and $\mathrm{V} \%(2)$ $(\mathrm{r}=0.324 ; \mathrm{p}=0.01)$, and a negative correlation with $\mathrm{H}+\mathrm{Al}_{(2)}$ $(\mathrm{r}=-0.364 ; \mathrm{p}=0.01)$. 


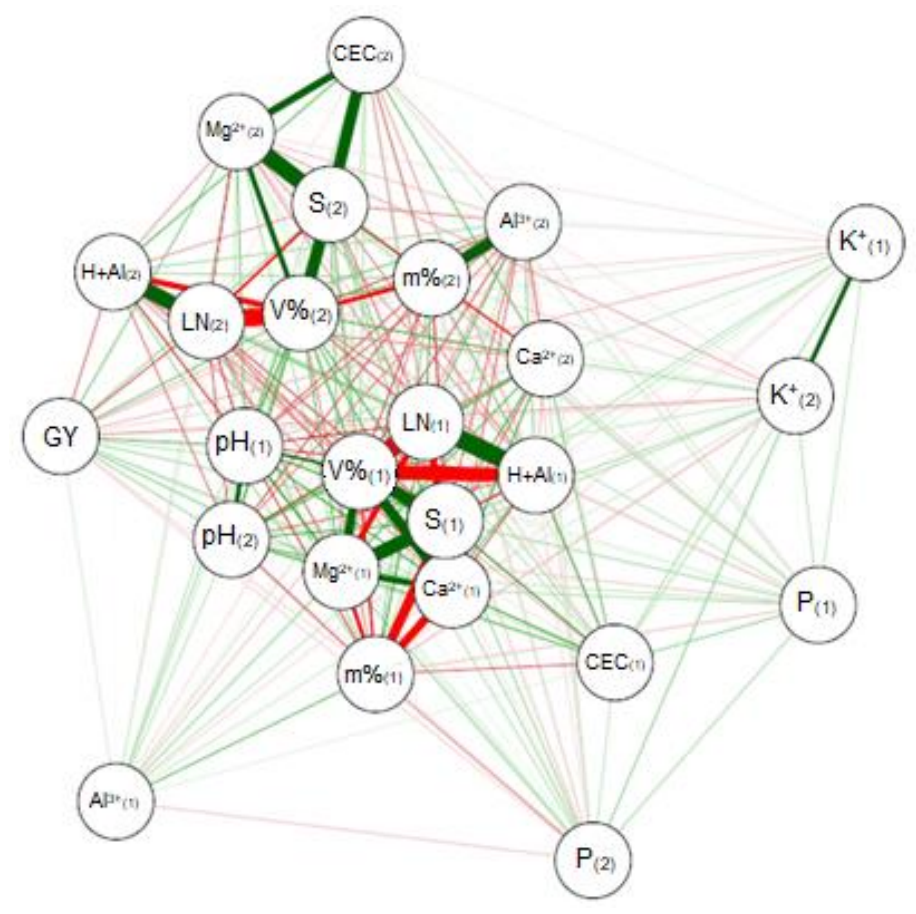

FIGURE 2. Correlation network of common bean grain yield and some chemical properties of a Brazilian Cerrado sandy soil, Cassilândia, MS, Brazil.

For the simple correlation between the GY and the chemical properties of the soil, a regression equation with $\mathrm{GY}$ as a function of $\mathrm{pH}_{(1)}$ was represented by a direct linear model (Eq. 1, Table 3 and Fig. 3a). This indicates a direct variation between cause and effect, and when the $\mathrm{pH}_{(1)}$ values reach a minimum (3.79), the estimated minimum GY will be $638.33 \mathrm{~kg} \mathrm{ha}^{-1}$. Dalchiavon et al. (2011) also reported a direct relationship between the GY of common beans and the soil $\mathrm{pH}$. The expression for GY as a function of $\mathrm{LN}_{(2)}$ was represented by an indirect exponential model (Eq. 2 and Fig. 3b), with a correlation coefficient value of $0.453(\mathrm{p}=0.01)$. Hence, the GY variation of the common bean crop can be explained by $45.3 \%$ of the variation in the $\mathrm{LN}$ data at a depth of $0.10-0.20 \mathrm{~m}\left(\mathrm{LN}_{(2)}\right)$. When $\mathrm{LN}_{(2)}$ is increased from 0 to $1,930 \mathrm{t} \mathrm{ha}^{-1}$, the GY may decrease from $1,249.6$ to $568.9 \mathrm{~kg} \mathrm{ha}^{-1}$. In turn, the expression for $\mathrm{GY}$ as a function of $\mathrm{V} \%_{(2)}$ was represented by a direct exponential model (Eq. 3 and Fig. 3c), with a correlation coefficient value of $0.349(\mathrm{p}=0.01)$. Thus, the variation in $\mathrm{GY}$ can be explained by $34.9 \%$ of the variation in the base saturation value at a depth of $0.10-0.20 \mathrm{~m}$. Hence, when $\mathrm{V} \%_{(2)}$ is increased from $3.8 \%$ to $84.1 \%$, GY may increase from 638.3 to $1,229.7 \mathrm{~kg} \mathrm{ha}^{-1}$. From the expression of GY as a function of $\mathrm{H}+\mathrm{Al}_{(2)}$, represented by a quadratic model (Eq. 4 and Fig. $3 \mathrm{~d})$, it can be observed that when $\mathrm{H}+\mathrm{Al}_{(2)}$ is increased from 4.1 to $25.9 \mathrm{mmol}_{\mathrm{c}} \mathrm{dm}^{-3}$, GY may decrease from $1,116.86$ to $561.03 \mathrm{~kg} \mathrm{ha}^{-1}$, reaching a point of maximum yield $\left(1,214.36 \mathrm{~kg} \mathrm{ha}^{-1}\right)$ when the potential acidity is $10.17 \mathrm{mmol}_{\mathrm{c}}$ $\mathrm{dm}^{-3}$. The expression for GY as a function of $\mathrm{Mg}^{2+}{ }_{(2)}$ content was represented by a direct potential model (Eq. 5 and Fig. $3 \mathrm{e})$, and when $\mathrm{Mg}^{2+}(2)$ is increased from 0.1 to $28.1 \mathrm{mmol}_{\mathrm{c}}$ $\mathrm{dm}^{-3}$, GY may increase from 903.1 to $1,270.3 \mathrm{~kg} \mathrm{ha}^{-1}$.

TABLE 3. Regression equation model for common bean grain yield as a function of some chemical properties of a Brazilian Cerrado sandy soil, Cassilândia, MS, Brazil.

\begin{tabular}{|c|c|c|c|c|c|c|}
\hline \multirow{2}{*}{ Mathematical model } & \multicolumn{5}{|c|}{ Adjustment coefficients } & \multirow{2}{*}{ Equation } \\
\hline & $\mathrm{a}$ & $\mathrm{b}$ & $\mathrm{c}$ & $\mathrm{R}$ & $r^{2}$ & \\
\hline $\mathrm{GY}=\mathrm{a}+\mathrm{b} \cdot\left(\mathrm{pH}_{(1)}\right)$ & -531.23 & $331.94 * *$ & - & $0.412 * *$ & $0.170 * *$ & {$[1]$} \\
\hline $\mathrm{GY}=\mathrm{a} \cdot \mathrm{EX} \mathrm{P}^{\mathrm{b} \cdot \mathrm{LN}(2)}$ & 1253.6 & $-0.332 * *$ & - & $0.453 * *$ & $0.205^{* *} *$ & {$[2]$} \\
\hline $\mathrm{GY}=\mathrm{a} \cdot \mathrm{EXP}^{\mathrm{b} . \mathrm{V} \%(2)}$ & 717.02 & $0.007 * *$ & - & $0.349 * *$ & $0.122 *$ & [3] \\
\hline $\mathrm{GY}=\mathrm{a}+\mathrm{b} \cdot\left(\mathrm{H}+\mathrm{Al}_{(2)}\right)-\mathrm{c} \cdot\left(\mathrm{H}+\mathrm{Al}_{(2)}\right)^{2}$ & 940.85 & 52.763 & $-2.642 *$ & - & $0.174 *$ & {$[4]$} \\
\hline $\mathrm{GY}=\mathrm{a} \cdot\left(\mathrm{Mg}^{2+}(2)\right)^{\mathrm{b}}$ & 989.95 & $0.063 * *$ & - & $0.371 * *$ & $0.137 * *$ & [5] \\
\hline
\end{tabular}

GY: grain yield $\left(\mathrm{kg} \mathrm{ha}^{-1}\right) ; \mathrm{pH}_{(1)}$ : soil $\mathrm{pH}$ value in the $0.0-0.10 \mathrm{~m}$ layer; $\mathrm{LN}_{(2)}$ : amount of limestone needed $\left(\mathrm{kg} \mathrm{ha}^{-1}\right)$ for the $0.10-0.20 \mathrm{~m}$ layer; V\%(2): soil base saturation (\%) in the $0.10-0.20 \mathrm{~m}$ layer; $\mathrm{H}+\mathrm{Al}_{(2)}$ : potential acidity $\left(\mathrm{mmol}_{\mathrm{c}} \mathrm{dm}^{-3}\right)$ in the $0.10-0.20 \mathrm{~m} \mathrm{layer}$; $\mathrm{Mg}^{2+}(2)$ : magnesium content $\left(\mathrm{mmol}_{\mathrm{c}} \mathrm{dm}^{-3}\right)$ in the $0.10-0.20 \mathrm{~m}$ layer. $* *$ and $*$ represent values that are significant at $1 \%$ and $5 \%$, respectively. 


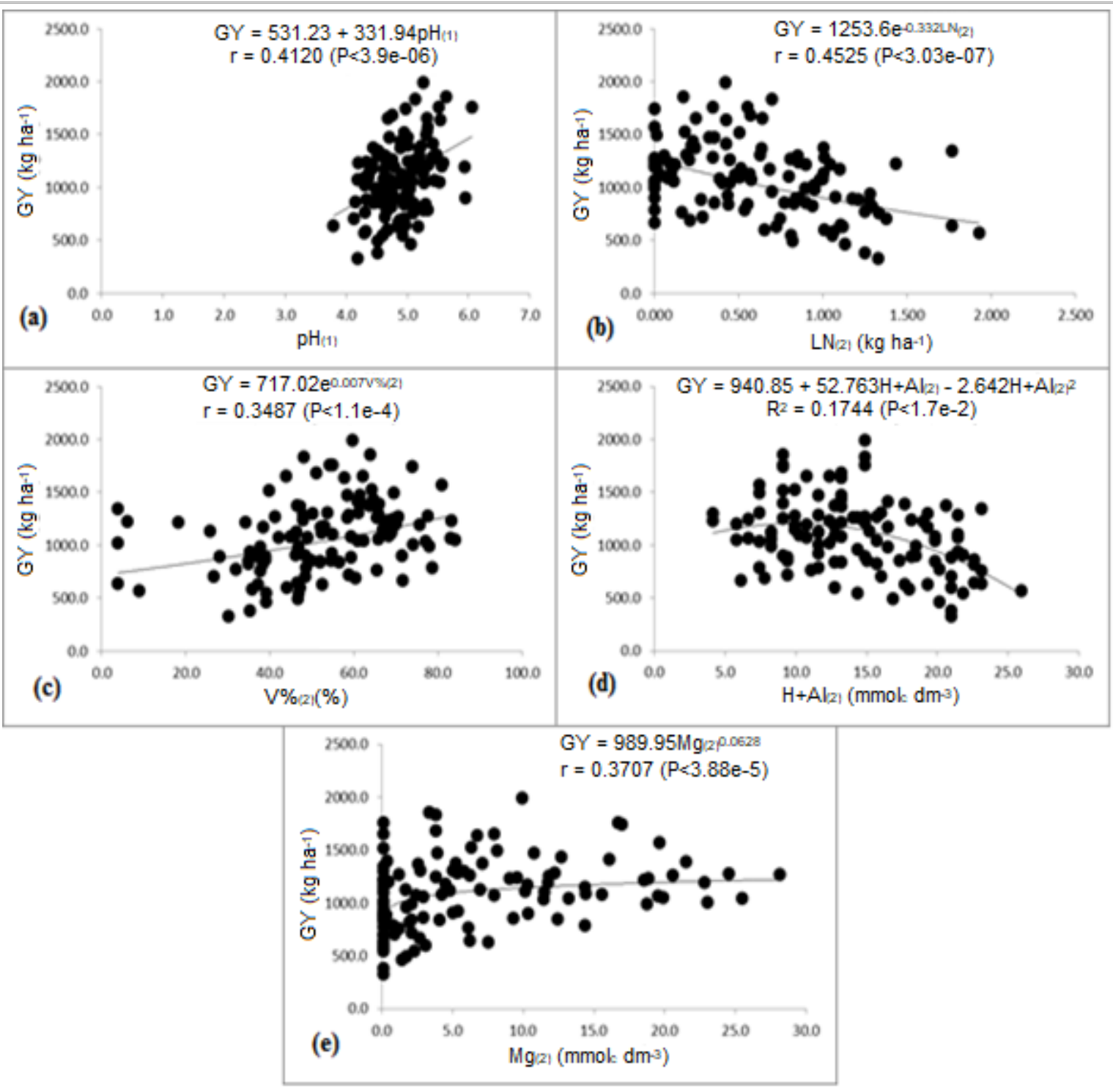

FIGURE 3. Regression equation for common bean grain yield (GY) as a function of: (a) soil $\mathrm{pH}$ in the $0.0-0.10$ layer [pH $\mathrm{pH}_{(1)}$; (b) amount of limestone needed for the $0.10-0.20 \mathrm{~m}$ layer $\left[\mathrm{LN}_{(2)}\right]$; (c) soil base saturation in the $0.10-0.20 \mathrm{~m}$ layer [V\% $\%_{(2)}$; (d) potential acidity in the $0.10-0.20 \mathrm{~m}$ layer $\left[\mathrm{H}+\mathrm{Al}_{(2)}\right]$; and (e) magnesium content in the $0.10-0.20 \mathrm{~m}$ layer $\left[\mathrm{Mg}^{2+}{ }_{(2)}\right]$ for a Brazilian Cerrado sandy soil, Cassilândia, MS, Brazil.

In the multiple regression analysis of GY as a function of all soil chemical properties, the models tested (Equations 6 and 7) explained approximately $31.3 \%$ of the variation in the common bean GY for a depth of $0.00-0.10 \mathrm{~m}$ depth $\left(\mathrm{r}^{2}=0.313 * *\right)$ and $31.1 \%$ for a depth of $0.10-0.20 \mathrm{~m}\left(\mathrm{r}^{2}=0.311 * *\right)$. Dalchiavon et al. (2011) reported that $22.1 \%$ of the variation in the common bean GY was explained by the characteristics of the $0.00-0.20 \mathrm{~m}$ layer of a Latossolo Vermelho eutroférrico.

$\mathrm{GY}=-2371.5+370.9 \mathrm{pH}_{(1)}+0.7 \mathrm{P}_{(1)}-1892.4 \mathrm{~K}_{(1)}^{+}-1728.7 \mathrm{Ca}^{2+}{ }_{(1)}-1629.1 \mathrm{Mg}^{2+}{ }_{(1)}+0.0 \mathrm{H}+\mathrm{Al}_{(1)}-236.8 \mathrm{Al}^{3+}{ }_{(1)}+1620.2$

$\mathrm{S}_{(1)}+64.5 \mathrm{CEC}_{(1)}+23.4 \mathrm{~V} \%_{(1)}+74.8 \mathrm{~m} \%_{(1)}-24.7 \mathrm{LN}_{(1)}$

$\mathrm{GY}=727.4+165.2 \mathrm{pH}_{(2)}-0.5 \mathrm{P}_{(2)}-4369.6 \mathrm{~K}_{(2)}-4296.7 \mathrm{Ca}^{2+}{ }_{(2)}-4266.6 \mathrm{Mg}^{2+}{ }_{(2)}+2650.9 \mathrm{H}+\mathrm{Al}_{(2)}-177.3 \mathrm{Al}^{3+}{ }_{(2)}+6855.2$

$\mathrm{S}_{(2)}-2602.8 \mathrm{CEC}_{(2)}+0.7 \mathrm{~V} \%(2)+4.5 \mathrm{~m} \%_{(2)}-904.3 \mathrm{LN}_{(2)}$

The geostatistical analysis (Table 3) showed that there were semivariograms spatial dependence for the following traits: $\mathrm{GY}, \mathrm{pH}_{(1)}, \mathrm{pH}_{(2)}, \mathrm{Ca}^{2+}{ }_{(2)}, \mathrm{H}+\mathrm{Al}_{(1)}, \mathrm{S}_{(2)}$, $\mathrm{m} \%_{(1)}$, and $\mathrm{LN}_{(2)}$. The cross-semivariograms $\mathrm{GY}=\mathrm{f}\left[\mathrm{pH}_{(1)}\right]$ and $\mathrm{GY}=\mathrm{f}\left[\mathrm{V} \%_{(2)}\right]$ were adjusted to a spherical model, while the simple semivariogram $\left(\mathrm{Mg}^{2+}{ }_{(1)}\right.$ and $\left.\mathrm{CEC}_{(2)}\right)$ and crosssemivariogram $\mathrm{GY}=\mathrm{f}\left[\mathrm{S}_{(2)}\right]$ were adjusted to an exponential model. Montanari et al. (2013b) also reported that spherical and exponential models were the most commonly used for soil and plant attributes. However, the chemical properties $\mathrm{P}_{(2)}, \mathrm{K}^{+}{ }_{(1)}, \mathrm{K}^{+}{ }_{(2)}, \mathrm{Ca}^{2+}{ }_{(1)}, \mathrm{Mg}^{2+}{ }_{(2)}, \mathrm{Al}^{3+}{ }_{(1)}$, $\mathrm{Al}^{3+}{ }_{(2)}, \mathrm{S}_{(1)}, \mathrm{CEC}_{(1)}, \mathrm{V} \%_{(1)}, \mathrm{V} \%_{(2)}$, and $\mathrm{LN}_{(1)}$, and the crosssemivariogram of $\mathrm{GY}=\mathrm{f}\left[\mathrm{pH}_{(2)}\right]$, were adjusted to a Gaussian model. These adjustments can be explained by the physical-chemical alterations of the soil, and mainly by the chemical properties, which are altered by correction and fertilization practices. 
The values of the relative ranges $\left(\mathrm{A}_{\mathrm{O}}\right)$ observed for the soil chemical properties and GY ranged from $9.0 \mathrm{~m}$ $\left(\mathrm{CEC}_{(1)}\right)$ to $51.0 \mathrm{~m}(\mathrm{GY})$ for the single semivariogram and $25.3 \mathrm{~m}\left[\mathrm{GY}=\mathrm{f}\left(\mathrm{pH}_{(2)}\right)\right]$ to $62.3 \mathrm{~m}\left[\mathrm{GY}=\mathrm{f}\left(\mathrm{pH}_{(1)}\right)\right]$ for the cross-semivariogram. In view of the way in which this research was conducted and using the same soil characteristics, it is suggested that the values of these ranges should be no less than $9.0 \mathrm{~m}$, since this represents the distance within which the values of each property are consistent (Table 4).

TABLE 4. Estimated parameters for simple or cross-semivariogram of the common bean grain yield with some of the chemical properties of a Brazilian Cerrado sandy soil, Cassilândia, MS, Brazil.

\begin{tabular}{|c|c|c|c|c|c|c|c|c|c|c|c|}
\hline \multirow{2}{*}{ Attributes $^{(a)}$} & \multirow{2}{*}{ Model $^{(b)}$} & \multirow{2}{*}{$\begin{array}{c}\text { Nugget } \\
\mathrm{C}_{\mathrm{O}}\end{array}$} & \multirow{2}{*}{$\begin{array}{c}\text { Sill } \\
\mathrm{C}_{\mathrm{O}}+\mathrm{C}\end{array}$} & \multirow{2}{*}{$\begin{array}{l}\text { Range } \\
\mathrm{A}_{\mathrm{O}}(\mathrm{m})\end{array}$} & \multirow{2}{*}{$r^{2}$} & \multirow{2}{*}{$\mathrm{SRS}^{(\mathrm{c})}$} & \multicolumn{2}{|c|}{$\mathrm{SDE}^{(\mathrm{d})}$} & \multicolumn{3}{|c|}{ Cross-validation } \\
\hline & & & & & & & $\%$ & Class & $\mathrm{a}$ & $\mathrm{b}$ & $\mathrm{r}$ \\
\hline & & & & Simnl & & $P l$ & at attrib & & & & \\
\hline \multirow[t]{2}{*}{ GY } & $\mathrm{sph}$ & $3.82 \times 10^{4}$ & $1.58 \times 10^{5}$ & 51.0 & 0.866 & $3.13 \times 10^{9}$ & 75.8 & Strong & 91.06 & 0.917 & 0.651 \\
\hline & \multicolumn{11}{|c|}{ y(h) Simple semivariogram - Soil attribute } \\
\hline $\mathrm{pH}_{(1)}$ & $\mathrm{sph}$ & $3.64 \times 10^{-2}$ & $2.00 \times 10^{-1}$ & 26.9 & 0.953 & $6.32 \times 10^{-4}$ & 81.8 & Strong & 0.19 & 0.960 & 0.716 \\
\hline $\mathrm{pH}_{(2)}$ & $\mathrm{sph}$ & $7.44 \times 10^{-2}$ & $1.29 \times 10^{-1}$ & 17.0 & 0.612 & $1.32 \times 10^{-2}$ & 42.5 & Moderate & 0.03 & 0.997 & 0.474 \\
\hline$P_{(1)}$ & pne & $1.77 \times 10^{1}$ & $1.77 \times 10^{1}$ & - & - & - & - & - & - & - & - \\
\hline$P_{(2)}$ & gau & $8.00 \times 10^{1}$ & $1.33 \times 10^{2}$ & 18.2 & 0.789 & $7.56 \times 10^{2}$ & 40.1 & Moderate & -0.03 & 1.013 & 0.455 \\
\hline $\mathrm{K}_{(1)}^{+}$ & gau & $8.20 \times 10^{-2}$ & $2.25 \times 10^{-1}$ & 12.2 & 0.712 & $1.51 \times 10^{-2}$ & 63.6 & Moderate & 0.12 & 0.881 & 0.554 \\
\hline $\mathrm{K}^{+}(2)$ & gau & $2.15 \times 10^{-1}$ & $3.60 \times 10^{-1}$ & 43.0 & 0.239 & $5.00 \times 10^{-2}$ & 40.3 & Moderate & 0.00 & 1.010 & 0.498 \\
\hline $\mathrm{Ca}^{2+}{ }_{(1)}$ & gau & $6.00 \times 10^{0}$ & $1.50 \times 10^{1}$ & 11.0 & 0.768 & $2.50 \times 10^{1}$ & 60.6 & Moderate & 5.53 & 0.594 & 0.355 \\
\hline $\mathrm{Ca}^{2+}{ }_{(2)}$ & $\mathrm{sph}$ & $5.00 \times 10^{0}$ & $1.05 \times 10^{1}$ & 32.0 & 0.954 & $1.72 \times 10^{0}$ & 52.4 & Moderate & 0.20 & 0.979 & 0.556 \\
\hline $\mathrm{Mg}^{2+}(1)$ & $\exp$ & $1.15 \times 10^{0}$ & $2.55 \times 10^{0}$ & 13.0 & 0.546 & $4.55 \times 10^{-1}$ & 54.8 & Moderate & 0.79 & 0.723 & 0.324 \\
\hline $\mathrm{Mg}^{2+}{ }_{(2)}$ & gau & $3.00 \times 10^{1}$ & $5.70 \times 10^{1}$ & 26.0 & 0.819 & $1.94 \times 10^{2}$ & 47.4 & Moderate & 1.84 & 0.720 & 0.366 \\
\hline $\mathrm{H}+\mathrm{Al}_{(1)}$ & $\mathrm{sph}$ & $8.00 \times 10^{0}$ & $2.30 \times 10^{1}$ & 12.0 & 0.720 & $3.68 \times 10^{1}$ & 65.2 & Moderate & 1.86 & 0.853 & 0.439 \\
\hline $\mathrm{H}+\mathrm{Al}_{(2)}$ & sph & $1.57 \times 10^{1}$ & $2.86 \times 10^{1}$ & 34.3 & 0.855 & $2.26 \times 10^{1}$ & 45.2 & Moderate & 1.53 & 0.894 & 0.452 \\
\hline $\mathrm{Al}^{3+}(1)$ & gau & $3.00 \times 10^{-3}$ & $1.54 \times 10^{-2}$ & 11.0 & 0.790 & $2.91 \times 10^{-5}$ & 80.5 & Strong & 0.73 & -0.161 & 0.105 \\
\hline $\mathrm{Al}^{3+}{ }_{(2)}$ & gau & $0.00 \times 10^{0}$ & $1.00 \times 10^{-1}$ & 12.0 & 0.554 & $6.86 \times 10^{3}$ & 100.0 & Strong & 0.58 & 0.110 & 0.148 \\
\hline$S_{(1)}$ & gau & $1.23 \times 10^{1}$ & $2.50 \times 10^{1}$ & 12.0 & 0.394 & $1.34 \times 10^{2}$ & 51.0 & Moderate & 5.13 & 0.706 & 0.412 \\
\hline$S_{(2)}$ & sph & $4.30 \times 10^{1}$ & $6.17 \times 10^{1}$ & 17.0 & 0.309 & $8.80 \times 10^{2}$ & 30.3 & Moderate & 8.60 & 0.485 & 0.145 \\
\hline $\mathrm{CEC}_{(1)}$ & gau & $1.60 \times 10^{1}$ & $2.55 \times 10^{1}$ & 9.0 & 0.265 & $9.32 \times 10^{1}$ & 37.3 & Moderate & 13.39 & 0.569 & 0.237 \\
\hline CEC & $\exp$ & $5.20 \times 10^{1}$ & $6.90 \times 10^{1}$ & 16.0 & 0.561 & $8.17 \times 10^{1}$ & 24.6 & Weak & 23.14 & 0.252 & 0.063 \\
\hline $\mathrm{V} \%_{(1)}$ & gau & $7.77 \times 10^{1}$ & $1.88 \times 10^{2}$ & 10.7 & 0.512 & $6.73 \times 10^{3}$ & 58.6 & Moderate & 10.12 & 0.825 & 0.483 \\
\hline $\mathrm{V} \%_{(2)}$ & gau & $1.70 \times 10^{2}$ & $2.94 \times 10^{2}$ & 12.0 & 0.588 & $3.20 \times 10^{3}$ & 42.2 & Moderate & 13.85 & 0.734 & 0.358 \\
\hline $\mathrm{m} \%_{(1)}$ & $\mathrm{sph}$ & $6.20 \times 10^{-1}$ & $1.36 \times 10^{0}$ & 18.6 & 0.875 & $6.00 \times 10^{-2}$ & 54.5 & Moderate & 0.34 & 0.901 & 0.507 \\
\hline $\mathrm{m} \%_{(2)}$ & pne & $1.09 \times 10^{2}$ & $1.09 \times 10^{2}$ & - & - & - & - & - & - & - & - \\
\hline $\mathrm{LN}_{(1)}$ & gau & $9.68 \times 10^{-2}$ & $1.90 \times 10^{-1}$ & 13.0 & 0.461 & $6.49 \times 10^{-3}$ & 49.0 & Moderate & 0.05 & 0.893 & 0.491 \\
\hline \multirow[t]{2}{*}{$\mathrm{LN}_{(2)}$} & $\mathrm{sph}$ & $1.45 \times 10^{-1}$ & $2.36 \times 10^{-1}$ & 36.0 & 0.809 & $1.53 \times 10^{-3}$ & 38.6 & Moderate & 0.03 & 0.944 & 0.443 \\
\hline & \multicolumn{11}{|c|}{$\gamma(h)$ Cross-semivariogram $-[$ Plant $=f($ Soil attribute $)]$} \\
\hline $\mathrm{GY}=\mathrm{f}\left[\mathrm{pH}_{(1)}\right]$ & $\mathrm{sph}$ & $1.00 \times 10^{-1}$ & $1.06 \times 10^{2}$ & 62.3 & 0.926 & $7.89 \times 10^{2}$ & 99.9 & Strong & 324.50 & 0.961 & 0.715 \\
\hline $\mathrm{GY}=\mathrm{f}\left[\mathrm{pH}_{(2)}\right]$ & gau & $6.80 \times 10^{0}$ & $3.20 \times 10^{1}$ & 25.3 & 0.905 & $5.97 \times 10^{1}$ & 78.6 & Strong & 285.50 & 0.739 & 0.622 \\
\hline $\mathrm{GY}=\mathrm{f}\left[\mathrm{S}_{(2)}\right]$ & $\exp$ & $0.00 \times 10^{0}$ & $6.88 \times 10^{2}$ & 27.3 & 0.744 & $2.11 \times 10^{5}$ & 100.0 & Strong & 912.70 & 0.654 & 0.501 \\
\hline $\mathrm{GY}=\mathrm{f}\left[\mathrm{V} \%_{(2)}\right]$ & $\mathrm{sph}$ & $4.19 \times 10^{2}$ & $2.32 \times 10^{3}$ & 36.7 & 0.884 & $3.98 \times 10^{3}$ & 81.9 & Strong & 532.60 & 0.791 & 0.603 \\
\hline
\end{tabular}

(a) GY: grain yield $\left(\mathrm{kg} \mathrm{ha}^{-1}\right) ; \mathrm{pH}_{(1)}$ and $\mathrm{pH}_{(2)}$ : $\mathrm{pH}$ values in the $0.0-0.10$ and $0.10-0.20 \mathrm{~m}$ layers, respectively; $\mathrm{P}_{(1)}$ and $\mathrm{P}_{(2)}$ : phosphorus content $\left(\mathrm{mg} \mathrm{dm}^{-3}\right) ; \mathrm{K}^{+}{ }_{(1)}$ and $\mathrm{K}^{+}{ }_{(2)}=$ potassium content $\left(\mathrm{mmol}_{\mathrm{c}} \mathrm{dm}^{-3}\right) ; \mathrm{Ca}^{2+}{ }_{(1)}$ and $\mathrm{Ca}^{2+}{ }_{(2)}$ : calcium content $\left(\mathrm{mmol}_{\mathrm{c}} \mathrm{dm}^{-}\right.$

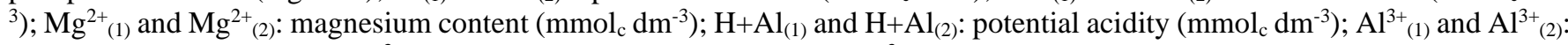
aluminum content $\left(\mathrm{mmol}_{\mathrm{c}} \mathrm{dm}^{-3}\right) ; \mathrm{S}_{(1)}$ and $\mathrm{S}_{(2)}$ : sum of bases $\left(\mathrm{mmol}_{\mathrm{c}} \mathrm{dm}^{-3}\right) ; \mathrm{CEC}_{(1)}$ and $\mathrm{CEC}_{(2)}$ : cation exchange capacity $\left(\mathrm{mmol}_{\mathrm{c}}\right.$ $\left.\mathrm{dm}^{-3}\right) ; \mathrm{V} \%_{(1)}$ and $\mathrm{V} \%_{(2)}$ : soil base saturation $(\%) ; \mathrm{m} \%_{(1)}$ and $\mathrm{m} \%_{(2)}$ : soil aluminum saturation; and $\mathrm{LN}_{(1)}$ and $\mathrm{LN}_{(2)}$ : amount of limestone needed $\left(\mathrm{kg} \mathrm{ha}^{-1}\right) .{ }^{(\mathrm{b})} \mathrm{sph}$ : spherical, exp: exponential, pne: pure nugget effect, and gau: Gaussian. ${ }^{\text {(c) }}$ SRS = sum of the residue square. ${ }^{(d)} \mathrm{SDE}=$ spatial dependence evaluation. 
The variation in the simple semivariograms, analyzed based on the magnitude of the spatial determination coefficient $\left(\mathrm{r}^{2}\right)$, was as follows: a lower value was found for $\mathrm{K}^{+}{ }_{(2)}(0.239)$ and a higher value for $\mathrm{Ca}^{2+}{ }_{(2)}$ (0.954). For the spatial dependence evaluator (SDE), the relationship was lower for $\mathrm{CEC}_{(2)}(24.6 \%)$ and higher for $\mathrm{Al}^{3+}{ }_{(2)}(100.0 \%)$. The attributes $\mathrm{Ca}$ and $\mathrm{V} \%$ had a low value of $r$, that is, a low-quality interpolation presented by crossvalidation, but even so it was possible to verify even if an existence of spatial dependence was low.

The performance of the cross-semivariograms (Table 4) in decreasing order, analyzed based on the spatial determination coefficient $\left(\mathrm{r}^{2}\right)$, was as follows: (i) [GY = $\left.\mathrm{f}\left(\mathrm{pH}_{(1)}\right)\right](0.926)$; (ii) $\left[\mathrm{GY}=\mathrm{f}\left(\mathrm{pH}_{(2)}\right)\right]$ (0.905); (iii) $[\mathrm{GY}=$ $\left.\mathrm{f}\left(\mathrm{V} \%_{(2)}\right)\right]$ (0.884); and (iv) $\left[\mathrm{GY}=\mathrm{f}\left(\mathrm{S}_{(2)}\right)\right]$ (0.744). In decreasing order, analyzed based on the magnitude of the range $\left(\mathrm{A}_{\mathrm{O}}\right)$, the results were as follows: (i) $\left[\mathrm{GY}=\mathrm{f}\left(\mathrm{pH}_{(1)}\right)\right]$ (62.3) $\mathrm{m}$; (ii) $\left[\mathrm{GY}=\mathrm{f}\left(\mathrm{V} \%_{(2)}\right)\right]$ (36.7) $\mathrm{m}$; (iii) $\left[\mathrm{GY}=\mathrm{f}\left(\mathrm{S}_{(2)}\right)\right]$ (27.3) $\mathrm{m}$; (iv) $\left[\mathrm{GY}=\mathrm{f}\left(\mathrm{pH}_{(2)}\right)\right](25.3) \mathrm{m}$.
In terms of cokriging, the best adjustments were between $\mathrm{GY}$ and $\mathrm{pH}_{(1)}$, and $\mathrm{GY}$ and $\mathrm{pH}_{(2)}$. It was observed that $92.6 \%\left(\mathrm{pH}_{(1)}\right)$ and $90.5 \%\left(\mathrm{pH}_{(2)}\right)$ of the spatial variability of the GY was explained by the spatial variability of the $\mathrm{pH}$ value of the soil, and the highest values for the yield were recorded in regions with higher soil $\mathrm{pH}$ values (Figure $4 \mathrm{~b}$ and $4 \mathrm{~d}$ ). The spatial dependencies for these cokriging results were high $\left(\mathrm{SDE}=99.9 \%\left[\mathrm{GY}=\mathrm{f}\left(\mathrm{pH}_{(1)}\right)\right]\right.$ and $\left.78.6 \%\left[\mathrm{GY}=\mathrm{f}\left(\mathrm{pH}_{(2)}\right)\right]\right)$, and the spherical and Gaussian types were adjusted to $\mathrm{pH}_{(1)}$ and $\mathrm{pH}_{(2)}$, respectively (Table 4, Figures $4 \mathrm{~b}$ and $4 d$ ). Similar results for cokriging between $\mathrm{GY}$ and the soil $\mathrm{pH}$ value were also reported by Montanari et al. (2013c), who found that the SDE was high $(99.0 \%)$, with a $13.0 \mathrm{~m}$ range and a Gaussian model adjustment. Figure 5 shows the kriging map of the common bean GY, which is very similar to the maps in Figure 4; the low productivity regions are in the northern region in all of the maps, and the regions with highest productivity are in the south. 


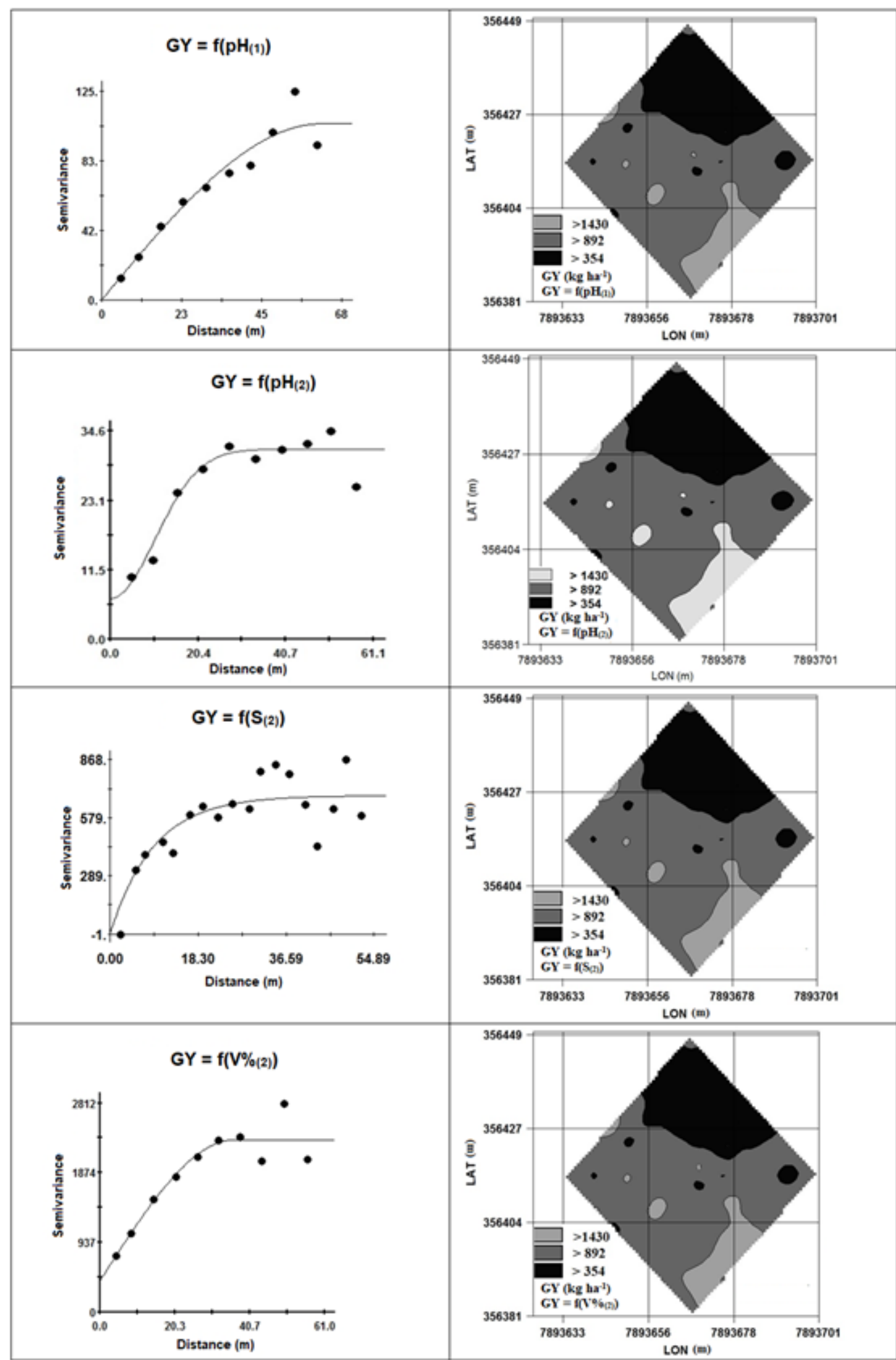

FIGURE 4. Cross-semivariograms and cokriging maps for common bean grain yield (GY) as a function of soil $\mathrm{pH}$ in the 0.0 0.10 layer $\left[\mathrm{pH}_{(1)}\right]$, soil $\mathrm{pH}$ in the $0.10-0.20$ layer $\left[\mathrm{pH}_{(2)}\right]$, sum of bases in the $0.10-0.20 \mathrm{~m}$ layer $\left[\mathrm{S}_{(2)}\right.$ ], and soil base saturation in the $0.10-0.20 \mathrm{~m}$ layer [V\%(2)] in a Brazilian Cerrado sandy soil, Cassilândia, MS, Brazil. 

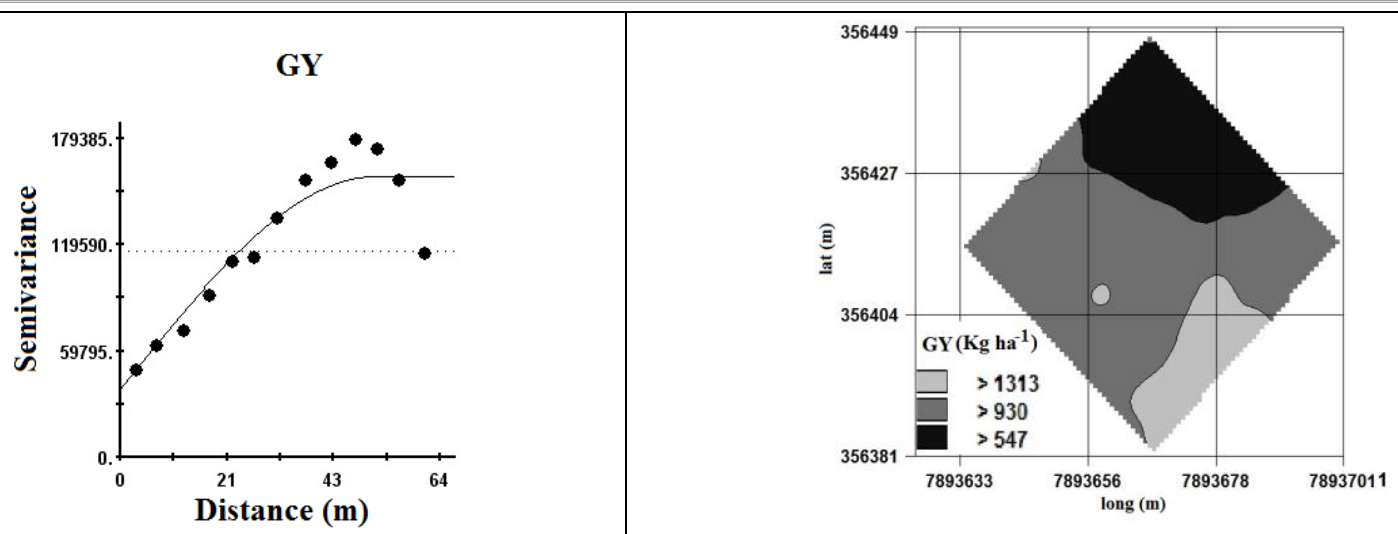

FIGURE 5. Semivariogram and kriging maps of common bean grain yield (GY) in a Brazilian Cerrado sandy soil, Cassilândia, MS, Brazil.

The cokriging results between $\mathrm{GY}$ and $\mathrm{S}_{(2)}\left(\mathrm{r}^{2}=\right.$ $0.744)$ and GY and V\%(2) $\left(\mathrm{r}^{2}=0.884\right)$ (Table 4) had exponential and spherical adjustments, respectively, for the cross-semivariograms, with ranges of 27.3 and $36.7 \mathrm{~m}$, and a high SDE was found for both (100.0\% and $81.9 \%)$. Thus, in relation to the properties $\mathrm{GY}=\mathrm{f}\left(\mathrm{S}_{(2)}\right)$, and $\mathrm{GY}=\mathrm{f}\left(\mathrm{V} \%_{(2)}\right)$, substantial elevations were found, with values ranging from 0.5 to $37.4 \mathrm{mmol}_{\mathrm{c}} \mathrm{dm}^{-3}$ for $\mathrm{S}_{(2)}$ and 3.8 to $84.1 \%$ for $\mathrm{V} \%_{(2)}$. The variation in the common bean GY was 328.2 to 1991.7 $\mathrm{kg} \mathrm{ha}^{-1}$.

It can be observed that the spatial variability between the chemical properties $\mathrm{pH}_{(1)}, \mathrm{pH}_{(2)}, \mathrm{S}_{(2)}$, and $\mathrm{CEC}_{(2)}$ with the GY of the common bean crop showed the same linear effect. Therefore, by cokrigagem of high significance, the GY of common beans can be estimated based on the direct effect of an increase in soil $\mathrm{pH}$, the sum of exchangeable bases and the percentage of the soil base saturation of the sandy soils of the Brazilian Cerrado.

\section{CONCLUSIONS}

For the GY of an irrigated common bean crop during the winter season, a multiple regression analysis indicated that $31 \%$ of the variation in production can be attributed to the spatial variability in all the chemical properties of a sandy soil of the Cerrado.

The chemical properties of the soil have a spatial dependence that is classified as moderate and strong, with a predominantly Gaussian-type semisvariogram model.

Properties such as $\mathrm{pH}_{(1)}, \mathrm{pH}_{(2)}, \mathrm{S}_{(2)}$ and $\mathrm{V} \%_{(2)}$ can be considered potential indicators of the GY of an irrigated common bean crop when cultivated in sandy soil with a notillage system.

\section{ACKNOWLEDGMENTS}

This study was financed in part by the Coordenação de Aperfeiçoamento de Pessoal de Nível Superior - Brasil (CAPES) - Finance Code 001 and Universidade Federal de Mato Grosso do Sul (UFMS).

\section{REFERENCES}

Bhering LL (2017) RBio: A tool for biometric and statistical analysis using the R platform. Crop Breeding and Applied Biotechnology 17:187-190. DOI: https://doi.org/10.1590/1984-70332017v17n2s29
Conab - Companhia Nacional de Abastecimento (2020) Perspectivas para a agropecuária, safra 2019/2020; Jan. 2020. Conab. v 7, Safra 2019/20 - N. 4 - quarto levantamento.

Dalchiavon FC, Carvalho MP, Freddi OS, Andreotti M, Montanari R (2011) Variabilidade espacial da produtividade do feijoeiro correlacionada com atributos químicos de um Latossolo Vermelho Distroférrico sob sistema de semeadura direta. Bragantia 70(4):908-916. DOI: https://doi.org/10.1590/S0006-87052011000400025

Embrapa - Empresa Brasileira de Pesquisa Agropecuária (2018) Brazilian soil classification system. Brasília, Embrapa Solos, 5 ed. 531 p.

Lima ES, Lovera LH, Montanari R, Panosso AR, Esteban DAA (2017a) Relações entre componentes morfológicos de palmito e atributos físicos de um inceptisol: Uma aproximação multivariada. Corpoica Cienc Tecnol Agropecuaria 18(3):543-554. DOI: http://dx.doi.org/10.21930/rcta.vol18_num3_art:743

Lima ES, Montanari R, Lovera LH, Teixeira Filho MCM, González AP (2017b) Variabilidade espacial das propriedades dendrométricas do eucalipto e atributos químicos de um Neossolo Quartzarênico. Revista de Agricultura Neotropical 4(1):1-11. DOI:

http://dx.doi.org/10.21930/rcta.vol18_num3_art:743

Montanari R, Pellin DMP, Júnior CAS, Carvalho MP, Gioia MT, Dalchiavon FC, González AP (2013a) Correlação entre produção de feijão e atributos físicos de um Latossolo em Mato Grosso do Sul. Revista Ceres 60(6):772-784. DOI: http://dx.doi.org/10.1590/S0034737X2013000600005

Montanari R, Carvalho MP, Filho MCMT, Dalchiavon FC. (2013b). Produção de matéria seca da braquiária de acordo com os atributos químicos de um Latossolo em Selvíria, Mato Grosso do Sul. Revista. Ceres 60(6):772-784. DOI: https://doi.org/10.1590/S0034-737X2013000400011

Montanari R, Carvalho MP, Junior CAS, Corrêa AR, Dalchiavon FC, González AP (2013c) Relations between the yield of common bean (Phaseolus vulgaris L.) and chemical attributes of an Acrustox under no-tillage. Journal of Soil Science and Plant Nutrition 13(2):367-379. DOI: http://dx.doi.org/10.4067/S071895162013005000030 
Montanari R, Lima ES, Lovera LH, Ferrari S, Queiroz HA (2016) Correlação dos componentes vegetativos da cultura da pupunha e dos atributos químicos do solo. Revista de Agricultura Neotropical 3(2): 25-33. DOI:

https://doi.org/10.32404/rean.v3i2.857

Oliveira JT, Carvalho MP, Roque CG, Baio FHR, Kamimura KM, Ribeiro IS, Teodoro PE (2018) Space variability of phenological indicators of common bean crop. Bioscience Journal 34(2):18. DOI:

https://doi.org/10.14393/BJ-v34n2a2018-39659

Silva MCC, Andreotti M, Costa NR, Lima CGR, Pariz CM (2017) Soil physical attributes and yield of winter common bean crop under a no-till system in the Brazilian Cerrado. Revista Caatinga 30(1):155-163. DOI:

https://doi.org/10.1590/1983-21252017v30n117rc
Tavanti RFR, Montanari R, Panosso AR, Freddi OS, González AP (2020a) Pedotransfer function to estimate the soil structural "s" index and spatial variability in an oxisol within a livestock farming system. Engenharia Agrícola 40(1):34-44. DOI: http://dx.doi.org/10.1590/1809-4430Eng.Agric.v40n1p34-44/2020

Tavanti RFR, Montanari R, Panosso AR, La Scala Jr N, Neto MC, Freddi OS, Gozález AP, Carvalho MAC, Soares MB, Tavanti TR, Galindo FS (2020b) What is the impact of pasture reform on organic carbon compartments and $\mathrm{CO}_{2}$ emissions in the Brazilian Cerrado? Catena 194:104702. DOI: https://doi.org/10.1016/j.catena.2020.104702

Teixeira PC, Donagemma GK, Fontana A, Teixeira WG (2017) Manual de métodos de análise de solo. Brasília, Embrapa, 3 ed. rev e ampl. 574 p. 